\title{
Re- inventing Governance and Public Accountability for Improved Productivity in Nigerian Higher Institutions
}

\author{
Femi Omotoso, PhD \\ Department of Political Science, \\ Ekiti State University, Ado-Ekiti, Nigeria. \\ E-mail: femot79@yahoo.co.uk
}

Doi:10.5901/ajis.2013.v2n3p89

\begin{abstract}
Higher institutions are established with the aim of producing qualified graduates that will eventually impact positively on national development but the achievement of this goal is being affected by the lack of development in these institutions. The majority opinion in the country today is that the quality of education is low, judging by the performance of the graduates of these institutions. Furthermore, so many people are of the opinion that effective governance and public accountability in the institutions are seriously in doubt, as there are reported cases of maladministration and misapplication or misappropriation of resources with severe consequences for manpower and infrastructural development. This paper therefore attempts to examine the veracity of these issues with a view to redefining governance and public accountability in higher institutions. The paper adopts governance and development approaches in analysing the issue in contention. It notes that the chief executives of the various higher institutions in Nigerian are excessively powerful particularly in area of general administration and fund utilisation. This in most cases has telling effects on the development of the institutions. The study concludes that for Nigerian higher institutions to effectively play their assigned roles, their governance and accountability must be improved upon.
\end{abstract}

Keywords: Nigeria, Governance, Public Accountability and Higher Institutions.

\section{Introduction}

The issues of good governance, quality and high productivity are of utmost concern to the Nigerian educational system. The majority opinion in the country today is that the quality of education is low arising from the poor administration of educational institutions and as manifested in the below-average performance of their products. Some have even attributed the problems of the Nigerian state to the low quality of graduates produced at the higher institutions of learning. This is logical in that a thoroughly educated man is more productive both to himself and the society. Sanda (1992:1) corroborates this. According to him, "the chronic ailments of contemporary Nigerian society derive from the decline in this society's quality of education".

So many reasons have been adduced for the low quality of education in Nigeria. These include paucity of financial resources available to the institutions' management, government's lack-lustre attitude, lip-service and cosmetic approach to educational issues, gross mismanagement, mal-administration, among others. This is manifested in lack of basic facilities to aid teaching and learning which invariably leads to job dissatisfaction and ultimately the scarcity of experienced academics, as so many of them have gone outside the country for greener pastures. All these have combined to adversely affect higher institutions and degenerated into a crisis in the educational system with devastating effects on quality and productivity.

The major factors in the production of qualitative graduates revolve around admissions, examination administration, course administration, certification and the recruitment and retention of experienced and hardworking workers. Where these functions are efficiently and effectively performed with sufficient social sensitivity, the outcome is good governance characterized by accountability, transparency, trust, and inclusive participation of all in decision making and policy implementation among others, Therefore, the delivery of these services requires careful, rigorous, painstaking and collaborative efforts, with a view to producing world-class graduates that can impact positively on both national and international developments.

The paper specifically focuses on ways of reinventing good governance and accountability in Nigerian higher institutions to reposition them for better and efficient service delivery. 


\section{An Assessment of the Nigerian Educational System}

The 1999 Nigerian constitution highlights the nation's educational objectives in Section 18 as follows:

(1) government shall direct its policy towards ensuring that there are equal and adequate educational opportunities at all levels;

(2) government shall promote science and technology;

(3) government shall strive to eradicate illiteracy; and to this end government shall as and when practicable provide:

(a) free, compulsory and universal education;

(b) free secondary education;

(c) free university education; and

(d) free adult literacy programme (FRN, 1999: 13).

Governments at all levels in Nigeria are paying only lip service to above- stated educational objectives of the country.

The Nigerian educational system is categorized into five, but the concern in this section is the assessment of higher education. Higher institutions, most especially the universities, are customarily centres for teaching, learning and research

The goals of higher education as highlighted by the National Policy on Education (1998) are:

(a) to contribute to national development through high-level relevant manpower training;

(b) to develop and inculcate proper values for the survival of the individual and the society;

(c) to develop the intellectual capability of individuals to understand and appreciate their local and external environment;

(d) to acquire both physical and intellectual skills which will enable individuals to be self-reliant and useful members of the society;

(e) to promote and encourage scholarship and community service;

(f) to forge and cement national unity; and

(g) to promote national and international understanding and interaction.

The realization of the above-stated goals has necessitated a rapid expansion of the Nigerian educational system at all levels, particularly at the higher level. Higher education is on the concurrent legislative list, and as such, both the federal and state governments have joint responsibilities. The liberalization of the education sector in Nigeria has equally allowed private participation in higher education. In this context, so many individuals, corporate bodies and religious organizations have been licensed to establish such institutions. Quite a number of private universities are thus in operation in Nigeria. It was, indeed, the promulgation of the National Minimum Standard and Establishment of Institutions Amendments Decree No. 9 of 1993 that paved the way for religious bodies, non-governmental organizations and private individuals to participate in the provision of higher education in the country. Bourner and Flowers (1999), as cited in Usoro (2011), highlighted the aims of higher education are to:

- disseminate knowledge;

- develop the capacity to use ideas and information;

- develop the students' idea to test ideas and evidence;

- facilitate the personal development of students; and

- develop the capacity of students to plan and manage their own learning.

The primary roles of higher educational institutions are the transmission of knowledge and skills and the training of human minds through teaching and research. Providing service to the community is an additional service (World Bank, 2000; Odebiyi and Aina 2000 as cited in Etudor-Eyo, 2011).

The decision roles of academic managers in higher institutions under education laws and policies according to Okeke (1985: 151), as cited in Bassey (2011: 93), include

- providing overall leadership, coordinating and accounting, evaluating that would encourage the empowerment of educational programmes

- being responsible for the welfare of staff, their professional development, training and morale

- being accountable for the success and safety of staff and students

- providing leadership in curricular review and development

- providing instructional leadership including supervision of instructions at the department level

- educational appraisals including students, lecturers and the programme. 
The National Universities Commission notes that the role of higher institutions has changed over time from preservers of culturally reversed forms of knowledge, through producers of skilled labour associated with a manpower planning approach, to a more recent perception as agents of social change and development (NUC: 2007). Usoro (2011: 20) observes that Nigerian higher institutions are ill-equipped to play the role expected of them. The public higher institutions are facing a lot of challenges arising from government insensitivity to the importance of education to national development. Owing to this, a lot of the elite are sending their children or wards to either private higher institution within the country or outside the country. Considerable challenges are confronting higher education in Nigeria; these challenges are multifaceted and they constitute major barriers to achieving the goals of higher education.

At this juncture, it is necessary to ask some fundamental questions? Are Nigerian higher institutions performing their expected roles efficiently and effectively? Or can their products compete favourably with their counterparts elsewhere? Do they meaningfully contribute to national development? The bottom line of all these is that the Nigerian educational sector is bedevilled by a number of factors which have combined to affect the quality of the products. Some of the problems include incessant closure of the institutions arising from avoidable strikes embarked upon by staff; unpredictable calendar as a result of strikes; under-funding; lack of autonomy; shortage of necessary facilities; student unrest; and cultism, among others. All these can be attributed to lack of managerial skills and the management style of the leadership of these institutions.

It is obvious that these institutions are too weak financially, structurally, materially and managerially to adequately contribute to national development. This could be traced to their long neglect as a result of military incursion into the nation's politics in 1966 and its perpetuation in power till early 1999 save October 1979- December 1983. This is apart from the lip-service commitment and cosmetic approach of the succeeding political class to issues of education. Owing to the participation of military in direct governance, all sorts of vices were accentuated in society, such as the culture of corruption, embezzlement, cronyism, ethnicity, "settlement", etc. This is not different from what is obtainable under democratic governance since 1999. Since higher institutions are products of the Nigerian society with no immunity to societal problems, they also became infested by these vices. It is a known fact that higher institutions are performing a lot of sensitive roles in the society as highlighted earlier, which ought to have influenced our leaders to insulate them from social vices, but this has not been the case. Hence, vices found fertile ground in these institutions and are affecting their efficiency and effectiveness. Another major challenge is the inability of the various governments - mostly the owners of these institutions - to provide necessary working tools, training and retraining of staff, sponsoring of staff, particularly academic staff, for conferences and seminars etc. All these are seriously affecting the quality of the products and the rating of these institutions.

\section{Public Accountability for Improved Productivity in Nigerian Higher Institutions}

Public trust in governance in Nigeria at all levels (higher institutions inclusive) is very low. This is as a result of various challenges confronting the nation which frustrate the efficiency of the public agencies. Some of such problems include corruption, weak governmental institutions, weak legislation, and insensitivity of public officials to peoples' plights. A respected academic, Prof Ladipo Adamolekun, while commenting on the systemic failure of public agencies in the country noted that "the public universities are almost uniformly in mediocre standards and their products are adjudged to be ill-prepared for employment in both the public and private sectors (2011: 42-57). This perhaps is the true reflection of higher institutions in Nigeria. In view of this, there is the need for a genuine demand that public sector institutions such as educational institutions at higher levels should strengthen ethics, integrity, transparency, accountability and professionalism, in order to protect public resources, achieve quality and enhance public sector performance. Most importantly, the institutions should be made and held accountable.

It is therefore necessary to conceptualise public accountability. Public accountability relates to issues of stewardship, in which case the elected or appointed leader is answerable for his or her actions, attitude or behaviour before a person or group of persons entitled to it. Public accountability is erected on the notion that all public servants are holding their positions in trust for the people who are the masters to whom they are responsible and accountable. Ezeani (2003: 5) observes that the concepts of "accountability" and "responsibility" have been used interchangeably. Accountability is often "assumed to mean to be responsible to somebody or for something. A person is responsible if he is expected to render an account or an explanation in respect of an assignment"

A number of types of public accountability can be identified which include: bureaucratic accountability, legal accountability, professional accountability, political accountability and financial accountability.

The question to ask at this juncture is that is higher institutions in Nigeria accountable? It may be very difficult to 
say that these institutions are accountable. The reason for this is not far-fetched as nearly all of them are not responsible to the public as they should be.

The rest of this section weighs Nigerian higher institutions against the typology of public accountability identified above.

\subsection{Bureaucratic Accountability}

It is expected that higher institutions should base their operations on the bureaucratic system which emphasises division of labour, span of control, hierarchical order, formalised system, impersonal structure, formalised rules and regulations, among others. This is with the aim of getting things done as and when due with ease. The situation in the various institutions may not be as smooth as what bureaucratic accountability envisages. Despite the fact that all necessary structures are in place with the personnel to manage them, things are unnecessarily slow. In fact, inefficiency is the key characteristic some of these institutions. Students' semester results are unnecessarily delayed, graduate students find it very difficult to collect transcripts, staff promotion is delayed, and file movement is slow, thereby invariably affecting policy implementation. The overall implication of such laxity and administrative lethargy on the system is organisational failure and internal conflicts; hence the usual complaints by Nigerians that these institutions provide services that are inadequate, inappropriate, inferior and or too costly to bear. For example, arbitrariness and high handedness characterised the administration of Professor Isa Muhammed, the Vice Chancellor at the University of Abuja, who unilaterally sacked thirty-five teachers, dissolved

Senate, created programmes and altered the academic structure of the university (Egbokhare, 2000). This created a huge problem for the university; so many courses were denied accreditation, inadequate teaching personnel to man various units in the university among others. It induced students' unrest and necessitated the Federal Government setting up a special visitation panel to look into the matter (Omomia, 2012).

\subsection{Legal Accountability}

Legal accountability "entails the frequent application of control to a wide range of public administration activities" (Ezeani, op.cit: 6). How far are these institutions applying control over staff, students and the general administration of the institutions? In some cases, rules are applied haphazardly; and staff and students are not treated fairly and equally. For example, promotion in most institutions is at the whims and caprices of the chief executive. Apart from this, most of these institutions often fail to honour their contractual obligations, particularly to the workforce. Also, most of these institutions are unable to work in harmony with the extant rule establishing them. It is noticeable as well that most of these institutions are incapable of rendering community service, thereby failing in fulfilling one of the missions of establishing them.

\subsection{Professional Accountability}

It is assumed that higher institutions recruit personnel based on their expertise. In line with the bureaucratic system, the officers so recruited are to function in various departments established with a view to rendering efficient and effective services to the people. The situation in most of these institutions does not support this time-tested bureaucratic tradition despite the availability of those "professionals" with the needed skills, and thus, it has been so difficult to guarantee efficiency and effectiveness in them. In some cases, many a qualified and competent staff member who can really deliver is sidelined simply because he or she is not in the good book of the chief executive or the management. Because of such professional irresponsibility, the work of the institution suffers.

\subsection{Political Accountability}

This simply refers to the responsiveness of the higher institutions' officials to the ultimate stakeholders, that is, the general public. Are the officials responsible and responsive to the general public in terms of service delivery? Are the people satisfied with the services of these officials? Or are they getting value for their money? Judging by the current performance rating of officials in these institutions, and the perception of Nigerians about them, it seems the general public is not so happy with their performance. 


\subsection{Financial Accountability}

This requires the officials in those institutions to use available fund judiciously and render accounts periodically on how the allocated fund is utilised. It is a known fact that nearly all public higher institutions are poorly funded, however, how well has the meagre fund made available been expended? This major challenge has made development extremely difficult in the institutions. For example, the management of Ahmadu Bello University, Zaria, "was found guilty in February this year of mismanagement of N50.5 billion fund meant for the running the University for 5 years" (Mahmud, 2012). Also, the panel investigating the maladministration in the university discovered a lot of ghost workers. According to Mahmud (ibid), "the university claiming to have a total workforce of 7793 , but only 6408 staff where discovered by the panel, with the rest suspecting to be ghost workers".

\subsection{Social Accountability}

This refers to the means whereby citizens demand responses from public officials concerning their actions and inactions. In other words, social accountability is about civic engagement in which the citizens demand accountability from their leaders. With regard to the higher institutions, the ability of the citizens to ask questions from the institution's management particularly on the welfare and general well being of their children or wards, is important. What is noticeable in Nigeria is that social accountability is on the low ebb. This is one of the challenges of these institutions. Since citizens are not putting the institutions' managers on their toes, the institutions are relaxed, complacent and are not so much alive to their responsibilities.

\section{Productivity in Nigerian Higher Institutions}

If accountability has been below par in Nigerian higher institutions, productivity has been equally damning.

Productivity is seen as "a measure of overall production efficiency, effectiveness and performance of the individual organization" (Udo-Aka 1983:68). It refers to the quality of output, workmanship, adherence to standards, absence of complaints, customer satisfaction, etc. (Ibid).

The abilities and efforts of the staff in any higher institution will determine the effectiveness and efficiency of the institution. In view of this; it is imperative on all staff to put in their best for the survival of the system. Rees-mogg William (1977 as cited in Onitiri 1983) recognized this fact when he noted that:

All that a worker has to sell is his productivity. His productivity is determined partly by his skill which itself depends both on his natural aptitudes and on his training and education, it depends also on the equipment he has to use and it depends on the efficiency with which his work is organized. Anything, which reduces the worker's productivity, is a direct attack on the worker's interest. To rob a worker of his productivity is like robbing a farmer of his crop; it is by its nature a crime.

What can be deduced from the above is that workers' productivity, as a matter of fact, is predicated solely on four major factors: skill, training, equipment and work organization. These four factors are essential to the institution's development and survival.

No doubt, poor motivation and poor standard of living reduce higher institution workers' productivity, and low productivity in turn reduces the capacity of the society. The question is what can be done to ensure higher productivity by the staff for better quality products?

Inyang (2001) sees productivity and quality improvement strategies as "those operational strategies that a manager utilizes to bring about increased performance level of employees in the organization, thus meeting targets or goals of the enterprise both qualitatively and quantitatively". With respect to higher institutions, it simply refers to strategies put in place by the administrators to boost the morale and enhance the performance level of the staff, with a view to repositioning, re-engineering and re-orientating the system for higher productivity and better services. To effectively do this, there is the need for recourse to the essential administrative functions of planning, organising, controlling, directing and coordinating. All these are to be used for the attainment of higher productivity in the system and for the institution to come up with qualitative products capable of meeting societal needs.

It is necessary for the management to know that human resources are crucial to the success of any organization and equally central to the decision-making process.

On productivity in higher institutions, the University of Botswana (UB) noted that a university categorised as excellent should have the following attributes or elements 
- academic staff renowned for research and scholarship

- highly competent teaching staff

- $\quad$ an effective system for managing both the academic and non-academic business of the university

- competent students who are motivated to learn

- resources such as laboratories and libraries that fully support the university's research and teaching activities (UB, 2005), as cited in Bassey (2011: 99).

The University of Botswana model can be adapted in Nigeria to bring excellence to the nation's educational sector.

Governance refers to the use of political powers to manage a nation's public affairs and to shape its economic and social environment in conformity with public interest and societal process. Boeninger (1992:267) observes that governance is seen "as the good government in society". It encompasses the just exercise of authority, the ability for problem solving, conflict resolution, the capacity for efficient management of resources for development, and a high level of responsiveness to the needs and interest of the general populace.

According to Gallagher (2001: 2), "Governance is the structure of relationships that bring out original coherence, authorise policies, plans and decisions, and account for their probity, responsiveness and cost effectiveness." Sharma (2007) and Kaul, as cited in Bassey (2011: 94) note that the essential characteristics of good governance are the rule of law, democracy, public accountability of government, public participation of government and implementation, decentralising governance, independence of the judiciary, merit principle in public management, equity in public policy, high standards of ethics, integrity in public bureaucracy, political leadership, responsible, responsive and humane public bureaucracy".

On governance in higher institutions, the appointment of the head of the institution in most cases does not follow merit but the prevailing political situation. For example, the ruling party will ensure that those appointed are either directly or indirectly affiliated to it. In some cases, particularly in states institutions, the chief executives of the institutions are removed for no offence(s) as soon as there is change of government. For example, in 2011, under the administration of Governor Kayode Fayemi, Ekiti state, in southwestern Nigeria, witnessed the dramatic dismissal of three state universities vice-chancellors namely, Prof. Dipo Kolawole (University of Ado- Ekiti), Prof. Sam Oye Bandele (University of Science and Technology, Ifaki- Ekiti) and Prof. in one fell swoop - a development unprecedented in the history of Nigerian universities (Fatunde, 2011). Also, "the governor of Edo State in southern Nigeria, Comrade Adams Oshiomhole, ordered the immediate removal of Professor Sam Uniamikogbo as vice-chancellor of the Ambrose Alli University in Ekpoma" (ibid). Furthermore, "Governor of Imo state Rochas Okorocha sacked Professor Bertrand Nwoke, acting vice-chancellor of Imo State University, and replaced him with Professor Osita Nwebo, also in an acting capacity. Okorocha's move was patently political; he simply dismissed Nwoke because he was appointed by his arch political rival, former Governor Ikedi Ohakim." (ibid). In all these scenarios, due process was not followed.

In addition, there is the issue of the appointment of members of the governing council. Governing councils of various higher institutions in Nigeria are populated by politicians. As such, they see themselves as representing and protecting the interests of Mr President and Mr Governor concerning federal and state higher institutions respectively, thereby constituting a major problem to the developmental agenda of the institutions. The politician-council member sees his or her appointment as a compensation for supporting Mr President or Mr Governor at the general election. Therefore, his or her major pre-occupation is to grab whatever benefits are available in the institution. Thus, they bid for contracts through surrogates, and such contracts are over-inflated. In some cases, after collecting substantial contract sums, they abandon the projects and the institution suffers while the institution managers are helpless in challenging this dastardly act because of the fear of political victimisation that might follow.

One of the problems of governance in higher institutions in Nigeria is contract administration. The institutions' managers often short-circuit the contract award processes. Tenders are manipulated to favour preferred bidders. In some cases, the managers resort to direct labour in carrying out projects. Also, they spilt a single contract into several bits to avoid open tender in a bid to cut corners. This has telling effects on infrastructural development; if contracts are inflated, it affects the quantity and quality of the projects.

Also, the institutions' managers are limited in the admission and recruitment of qualified students and staff based on merit and utility because of policies and principles like quota system, federal character and catchment area. Since they must abide by these policies and principles while admitting students and recruiting staff, it limits the quality of students and staff in the institutions. It affects productivity and demoralises the institutions' manager while carrying out the 'act of balancing'. In some cases, top-rated students and staff are left out, while mediocres are selected in a bid to comply with these policies and principles.

Another major problem is that government is merely spending on education rather than investing in it. In other 
words, governments at all levels are spending on education, by expending their resources on what cannot promote the goals of education. Investing in education has to do with prudently committing resources on solid infrastructural development in the institutions, capacity building for the staff, provision of standard laboratories and equipping the library with modern facilities, books, journals and other periodicals, among others. This will in turn promote and advance the goals of education in the country. Since government is equally guilty of this, it is quite impossible for it to compel the institutions' managers to invest in education properly; as such, the institutions lack basic amenities, staff are not well catered for, laboratories are in bad shape etc. This has definitely affected the quality of the products.

Good governance is therefore associated with the participation of all in decision making, transparency and accountability of leaders at all levels. It equally relates to effective and efficient coordination of men and use of resources and adherence to the rule of law in the decision making process.

Good governance is desirable in institutions of higher learning in Nigeria so as to combat and confront the major challenges of these institutions as earlier highlighted in this paper. The inability to maintain or put in place good governance in higher institutions in the country has led to what Ibukun (1987), as cited in Odu (2010), refers to the crises of management. He identified some of the observable issues relating to this to include:

- Financial crises

- Increasing cost of higher education

- Power relations and crises among formal and informal pressure groups

- Gross resource inadequacy to cope with student enrolment and modern technology

- Drug addiction and cultism

- Professor's politics and personnel management

- Autonomy conflict

- Brain drain syndrome.

The question is, what can be done to promote good governance and accountability in Nigerian higher institutions? This shall be our next focus in this paper.

\section{Towards Reinventing Good Governance and Accountability in Nigerian Higher Institutions}

It has been established in this paper that Nigerian higher institutions are not where they should be because of so many challenges arising from lack of accountability and good governance. It is imperative to draw out those issues that will therefore encourage and promote good governance and accountability in these institutions.

Leadership is key to development and good governance in any organisation. Leadership is seen as the basic influencing of individual and group behaviour towards optimal attainment of the organisational goals. These institutions need dynamic, hardworking, resourceful, selfless and committed leaders. Such leaders must be dedicated to the overall development of the institution. They must see to the effective and efficient management and utilisation of men and resources towards attaining the organisational goals. Echoing this, Bassey (op.cit::81), argues that:

leadership effectiveness in University management could be gauged through such indicators like efficiency in management, quality of infrastructure and equipment outfit, work morale and attitude level, academic standard, level of cultism and examination malpractices and perception of the institution by the community.

Furthermore, the leadership in these institutions should adopt the democratic leadership style. This style of administration allows for leaders to be closer to the people since it gives room for the participation of all stakeholders in the administration and management of any institution. Apart from this, the leader will not run the institution as a personal property, but, instead, he or she should make accountability his or her watchword. Such a leader would adopt transparency as a tool of management in such a way that the affairs of the institution will not be conducted in secret; the leader will subject his or her actions to public scrutiny by rendering stewardship accounts periodically.

In this leadership style, members of staff are allowed to have unhindered access to the leader to state grievances and come up with suggestions on how to move the institution forward. Such a leader will always motivate the staff, listen to them and encourage them towards higher productivity.

Leadership is germane to the success or otherwise of any organization, in that it symbolizes the organization and directs its affairs. A dynamic, dedicated and determined leadership will impact positively on the school system and will promote quality at all times. The right type of leadership, no doubt, emphasises quality and encourages higher productivity among the workers of the system. Sanda (op. cit: 38 ) has recognized the fact a long time ago. According to him, 
... staff recruitment, induction into the job, training and counselling of subordinates, performance appraisal or review and motivation of staff, all depended upon the administrative competence, objectivity and academic leadership of the head or acting head of department. The work environment and interpersonal relations at work may be facilitating or inhibitive for the lecturers, depending upon ability and orientation of the relevant head of department (ibid).

The issue here is that incapable and incompetent leadership is dysfunctional and unhealthy for higher institutions. A leadership lacking in technical and administrative competence cannot promote quality, as it will be unable to apply rules and regulations accordingly.

Odu (op.cit::369 - 376) has catalogued some of the measures that can assist higher institutions toward good governance and accountability to include:

- Shaping a new vision of higher education

- Long-term orientation based on relevance

- Strengthening cooperation with the world of work and analysing and anticipating societal needs

- Innovative educational approaches, critical thinking and creativity for national development

- Strengthening higher education management and financing

- Financing of higher education as a public service, and

- Sharing knowledge and know-how across borders and continents.

In conclusion, good governance and accountability are the hallmarks of effective service delivery and they equally promote higher productivity in an organisational setting. Therefore, leaders in higher institutions have a crucial role to play in guaranteeing the transparency, accountability and efficiency of the institutions.

The affairs of these institutions should be made open and accountable to the people so that the institutions' management can enjoy the support of the people at all times. This is not only in financial terms but also in general terms such as accepting responsibility for the outcome of their actions in deploying the human, financial and material resources of the institutions to achieve public goals.

\section{References}

Adamolekun, L (2011) "Rethinking Public Services in Nigeria" in Ladipo Adamolekun (ed) Ideas for Development Proceedings of lju Public Affairs Forum Series, 2006-2009. Ibadan, Carligate Publishing Company Limited.

Bassey, S.U (2011) "Leadership and Corporate University Governance" in Bassey, S.U and Bassey, U.U (eds) Management of Higher Education in Africa, Uyo, Abaam Publishing Co Books Ltd.

Bourner, T \& Flowers, S (retrieved, 2001) Teaching and Learning Methods in Higher Education: A Glimpse of the Future. Retrieved 2001 from http;//www.bbk.ac.uk/asd/bourne.hvm

Egbokhare, F. (2000). Nigerian Universities Today: Imperatives for Change and Relevance. Recall: A Chronicle of Nigerian Events, 1.

Etudor- Eyo (2011) "Higher Education in Nigeria" in Bassey, S.U and Bassey, U.U (eds) Management of Higher Education in Africa, Uyo, Abaam Publishing Co

Ezeani. E.O (2003) "Public Accountability Conceptual Analysis, in Ezeani, E.O (ed) Public Accountability in Nigeria: Perspectives and Issues, Enugu, Academic Publishing Company

Fatunde, T. (2012) "NIGERIA: State Vice-Chancellor Jobs Precarious" in University World News 10 Oct

FRN (1981) National Policy on Education Lagos: Federal Government

Gallagher, M (2001) Modern University Governance: National Perspective, Paper Presented at a conference Organised by Australia Institute of Manning Clark House, The Autralian National University, (July)

Inyang B. J. (2001) "Productivity and Quality Improvement Strategies for Enhancing Corporate Survival in a Competition - Driven Economy" in African Journal of Business and Economic Research Vol. 2. No 1 \& 2

Kaul, M (2000) An Outsider's Inside View: Management Reforms in Government: A Review of International Practices and Strategies, London, CAPAM \& COMSEC

Mahmud, S. (2012) "Corruption in the Nigerian University System" in Nigerian Pilot, August 06.

National Universities Commissions (NUC, 2007) Benchmarks Minimum Academic Standards of Programmes in Nigerian Universities, edited for FEC Approval Vol.2 No 14 April

Odebiyi, A.I and Aina, Q.I (2000) Financing Higher Education in the Federal Republic of Nigeria: Development and Trends, www.dawodu.com/educ/htm

Odu, B.K (2010) "Higher Education Administration for National Development"in Omotoso, F., Agagu, A.A., and Abegunde, O. (eds) Governance, Politics and Policy in Nigeria: An Essay in Honour of Prof. Dipo Kolawole. Porto Novo: Editions SONOU d' Afrique (ESAF)

Omomia, K. (2012) "Rescuing University of Abuja" in Nigerian Pilot

Onitiri, H.M.A (1983) "Productivity and Economic Development" in Osoba, A.M (ed) Productivity in Nigeria Proceedings of a National Conference , Productivity Prices and Incomes Board and Nigerian Institute of Social and Economic Research 
Osoba A. M. (ed) (1983)Productivity in Nigeria. Nigeria: Productivity Prices and Income Board and NISER.

Rees-Mogg, W. (1977) "The Machinery for Wasting Manpower" in London Times October 5

Sanda A. O. (1992): Managing Nigerian Universities Ibadan: Spectrum

Sharma, K.C (2007) "Towards Good Governance in Africa: Critical Dimensions and Challenges" in R.B Jain (ed) Governing Development Across Cultures: Challenges and Dilemmas of an Emerging Sub- Discipline in Political Science, Opalde, Germany: Barbara Budrich Publishers

UB (University of Bostwana) (2005) Performance Management System Manual

Udo-Aka Udo (1983) "Measuring Productivity: Issues and Problems" in Usoro, E.B (2011) "Functions of the University" in Bassey, S.U and Bassey, U.U (eds) Management of Higher Education in Africa, Uyo, Abaam Publishing Co.

World Bank (2000) Higher Education in Developing Countries: Peril and Promise. Washington DC, The World Bank.http://.nigeriaworld.com/articles/2008/sep/300.html 
